\title{
Cell Cycle
}

National Human Genome Research Institute (NHGRI)

\section{Source}

National Human Genome Research Institute (NHGRI). Cell Cycle.

A cell cycle is a series of events that takes place in a cell as it grows and divides. A cell spends most of its time in what is called interphase, and during this time it grows, replicates its chromosomes, and prepares for cell division. The cell then leaves interphase, undergoes mitosis, and completes its division. The resulting cells, known as daughter cells, each enter their own interphase and begin a new round of the cell cycle. 


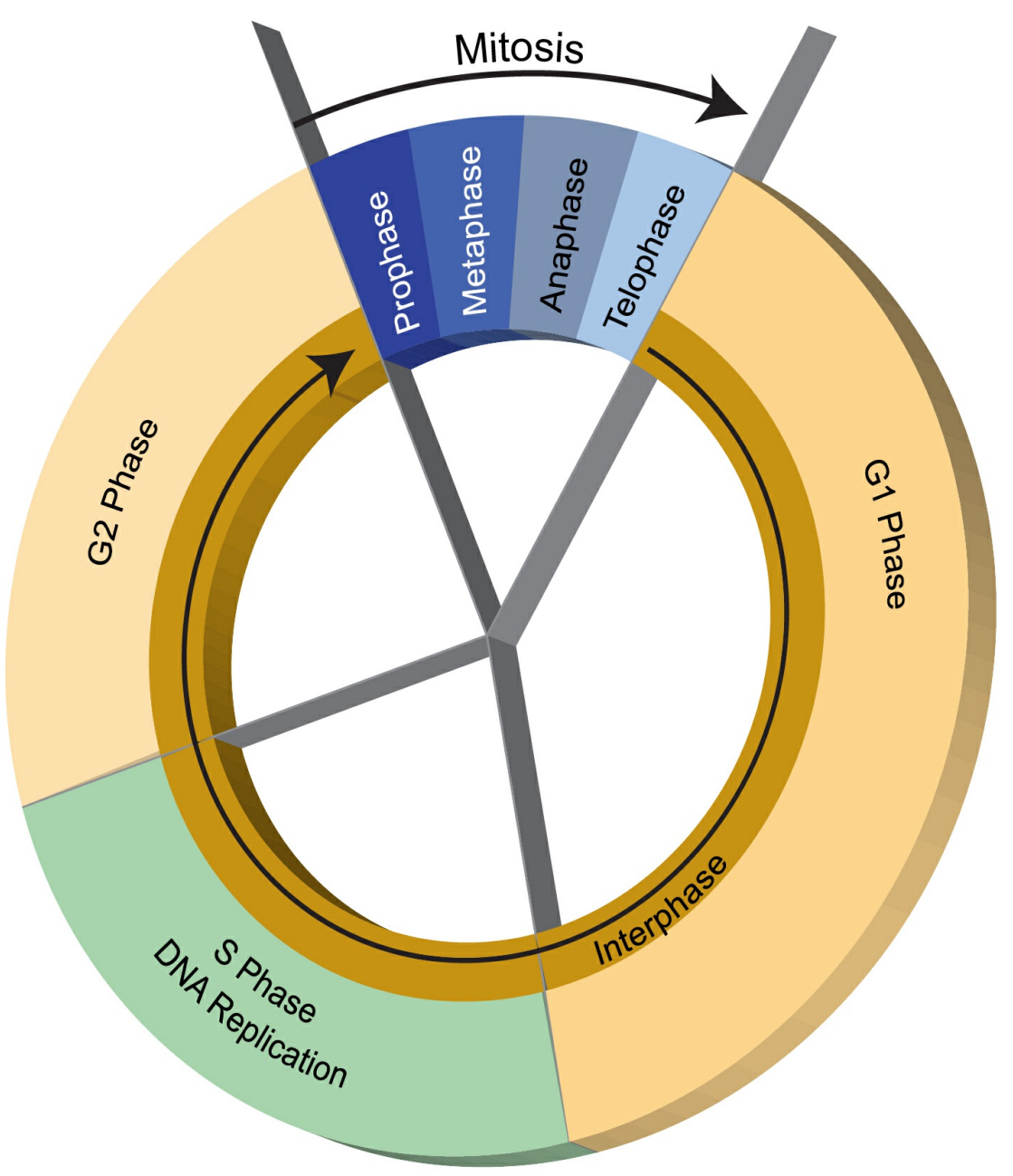

